\title{
Use of Prucalopride for Chronic Constipation: A Systematic Review and Meta-analysis of Published Randomized, Controlled Trials
}

\author{
Muhammad S Sajid, ${ }^{1 *}$ Madhu Hebbar, ${ }^{1}$ Mirza K Baig, ${ }^{1}$ Andy Li,${ }^{2}$ and Zinu Philipose ${ }^{2}$ \\ ${ }^{\prime}$ Department of General, Endoscopic and Laparoscopic Colorectal Surgery, Western Sussex Hospitals NHS Foundation Trust, Worthing Hospital, \\ Worthing; UK; and ${ }^{2}$ Department of Gastroenterology, Gastrointestinal Endoscopy and Hepatology, Western Sussex Hospitals NHS Foundation \\ Trust, Worthing Hospital, Worthing, UK
}

This article highlights the role of prucalopride in the management of chronic constipation based upon the principles of meta-analysis using data reported in the published randomized, controlled trials. Sixteen randomized, controlled trials on 3943 patients reported the effectiveness of prucalopride in patients with chronic constipation. Prucalopride successfully increased the frequency of spontaneous bowel movements per week in all variable doses of $1 \mathrm{mg}$ (standardized mean difference [SMD], $0.42[95 \% \mathrm{Cl}, 0.18-0.66 ; P=0.006]$ ), $2 \mathrm{mg}(\mathrm{SMD}, 0.34$ [95\% Cl, 0.11-0.56; $P=0.003])$, and $4 \mathrm{mg}(\mathrm{SMD}, 0.33[95 \% \mathrm{Cl}, 0.22-0.44 ; P=0.00001])$. The risks of adverse events or side effects such as headache, abdominal cramps, excessive flatulence, dizziness, diarrhea, and rash were higher (odds ratio, $1.70[95 \% \mathrm{Cl}, 1.27$ to $-2.27 ; P=0.0004])$ in prucalopride group. Prucalopride is clinically a beneficial pharmacotherapy for chronic constipation and its routine use may be considered in patients with chronic simple laxative-resistant constipation.

(J Neurogastroenterol Motil 2016;22:412-422)

Key Words

Constipation; Functional bowel disorders; Laxatives; Prucalopride; Secondary constipation

\section{Introduction}

Chronic constipation is largely divided into 2 major categories: functional (primary) and secondary. Functional constipation is defined by the Rome III diagnostic criteria ${ }^{1}$ and may additionally be sub-divided into the normal transit constipation, slow transit constipation, and defecation disorders. ${ }^{2}$ Secondary constipation is caused by conditions and medication use such as diabetes mellitus, hypothyroidism, depression, opioids, anti-depressants, and calcium channel blockers. ${ }^{3,4}$ Just like the complexity in the definition of the functional and secondary constipation, the management pathway is also understandably difficult and challenging for both gastrointestinal physicians and gastrointestinal surgeons. Majority of the constipation experts offers several interventions to manage chronic constipation, with initial advice of life style change and failure to

Received: January 8, 2016 Revised: February 14, 2016 Accepted: March 5, 2016

() This is an Open Access article distributed under the terms of the Creative Commons Attribution Non-Commercial License (http://creativecommons. org/licenses/by-nc/4.0) which permits unrestricted non-commercial use, distribution, and reproduction in any medium, provided the original work is properly cited.

${ }^{*}$ Correspondence: Muhammad S Sajid, FRCS

Associate Specialist in General and Colorectal Surgery, Worthing Hospital, Worthing West Sussex, BN11 2DH, UK Tel: +44-01903-205-111, Fax: +44-01903-285-010, E-mail: surgeon1wrh@hotmail.com

The provisional abstract of this study has been presented as a poster at the 102nd Annual Congress of the Association of Surgeons of Great Britain and Ireland in Manchester on 22nd-24th April 2015. The abstract is published with citation of Br J Surg 2015;102(S7);140. 
this approach leads to the use of osmotic laxatives (lactulose), bulkforming laxatives (ispaghula husk), and stimulant laxatives (senna). In addition, the use of macrogol, bisacodyl or glycerol suppository, sodium phosphate, and arachis oil enema is also a common practice prior to the use of relatively innovative agents. ${ }^{5-15}$ Non-pharmacological interventions such as ritualizing bowel habits, biofeedback therapy, behavior therapy, electrical stimulation of pelvic muscles, cognitive therapy, and surgical sub-total colectomy have been reported, mainly from tertiary centers with variable effectiveness, and in the selected group of patients with chronic constipation. ${ }^{16-19}$

Among novel pharmacological agents, cisapride, a pro-motility medicine, which acts as gut prokinetic therapy, was used clinically for the treatment of chronic constipation and studies reported cisapride effectively reduced the need for first and second line laxatives with optimized stool consistency, but failed to demonstrate effect on gut peristalsis in patients with chronic idiopathic constipation. ${ }^{20}$ Tegaserod, a selective 5-hydroxytryptamine $4\left(5-\mathrm{HT}_{4}\right)$ receptor agonist, is reported to be a more successful novel pharmacotherapy agent than placebo in providing relief from the symptoms of chronic constipation, including increased bowel-movement frequency, decreased straining, or hard or lumpy stool in addition to reduced abdominal discomfort/pain, and bloating/distension. ${ }^{23-25}$ A systematic review for constipation concluded that tegaserod successfully improved numerous symptoms in patients with chronic constipation. ${ }^{26}$ Lubiprostone is a digestive system-targeted bicyclic functional fatty acid that activates chloride channel type- 2 in the apical membrane of the gut mucosal epithelium causing increased intestinal water secretion and subsequently enhancing the secretion of chloride leads to an increase in intraluminal fluid in the bowel, which facilitates transit in the intestine and thereby eases stool passage. The efficacy of lubiprostone in the treatment has been reported in many studies, including 2 identical placebo-controlled trials ${ }^{27-32}$ but for some reason it failed to attain popularity among gastrointestinal physicians and surgeons, possibly due to side effects.

The fourth novel agent prucalopride, another 5- $\mathrm{HT}_{4}$ agonist and a unique enterokinetic therapy has also been proven equally effective, and it is the only agent which is recommended by the National Institute For Health Care Excellence (NICE) for chronic constipation in women. This article highlights the role of prucalopride in the management of chronic constipation based upon the principles of meta-analysis using data reported in published randomized, controlled trials as reported by the Cochrane Collaboration.

\section{Materials and Methods}

Electronic medical databases such as the Medline, EMBASE, Cochrane Colorectal Cancer Group Controlled Trial Register, Pain, Palliative and Supportive Care Group Controlled Trial Register, Dementia and Cognitive Improvement Group Controlled Trial Register, Developmental, Psychosocial and Learning Problems Group Controlled Trial Register, Multiple Sclerosis and Rare Diseases of the CNS Group Controlled Trial Register, and the Cochrane Central Register of Controlled Trials (CENTRAL) in the Cochrane Library along with the Science Citation Index Expanded were explored until May 2015 to find published randomized, controlled trials. The MeSH terms related to prucalopride and chronic constipation were retrieved from the search engine PubMed, and were used to search the aforementioned electronic databases. Attempts to include additional studies were also made by hand searching of citations of published studies. The statistical analysis of the extracted data was conducted according to the guidelines provided by the Cochrane Collaboration including the use of RevMan 5.3 statistical software, random-effects model analysis, heterogeneity testing by Chi-squared test, heterogeneity quantification by Isquared test, and the use of forest plots for the graphical display of the combined outcomes. ${ }^{33-39}$ The combined analysis of continuous variables was expressed as standardized mean difference (SMD) and combined variables were expressed as odds ratio (OR). The primary outcome measure was the incidence of spontaneous bowel movements (SBMs) per week, and the secondary outcome measure was adverse events or side effects of prucalopride use (complications). The reported side effects of prucalopride such as abdominal cramps, abdominal pain, nausea, vomiting, dizziness, diarrhea, rash, headache, constipation, bradycardia, skin disorders, and flatulence were jointly reported in published trials and were analysed in same way in the current article. The critical appraisal tool to score the quality of included trials was adopted from the published guidelines of Jadad et $\mathrm{al}^{40}$ and Chalmers et $\mathrm{al}^{41}$ The short summary of the resulting evidence was presented in a tabulated form by using the tool GradePro, ${ }^{42}$ provided by the Cochrane Collaboration. The authors agreed to include all published randomized, controlled trials in patients of any age and gender, diagnosed with chronic constipation of any etiology. The authors excluded studies on animals.

\section{Results}

The Preferred Reporting Items for Systematic Reviews and 
Meta-Analyses (PRISMA) flow chart to explain the literature search strategy and trial selection is given in Figure 1. Sixteen randomized, controlled trials ${ }^{43-58}$ on 3943 patients were retrieved from the search of standard medical electronic databases. The characteristics, salient features and treatment protocols adopted in the included randomized, controlled trials are given in the Table. All trials were adequately randomized using either computer generated sequential pattern or other reliable random pattern methods. These trials varied from phase $\mathrm{II}^{46}$ to phase $\mathrm{III},{ }^{51}$ and were placebo-controlled $^{4-58}$ with either single or double blinding. Power calculations, type I and type II errors were adequately covered in the majority of trials. The trial quality indicator Jadad score of included randomized, controlled trials was 4.3 (3.1-5.0). However, the intention-totreat analysis was lacking in the majority of the trials. The included trials investigated the clinical effectiveness of prucalopride recruiting patients in either $1 \mathrm{arm}^{47-49,51,58}$ or $2 \mathrm{arms}^{44,45,50,53-57}$ or even in some cases, 3 arms. ${ }^{43,46,52}$ There were diverse inclusion and exclusion criteria in reported randomized, controlled trials and duration of prucalopride use ranged from 1-12 weeks. Although several primary and secondary outcome measures were reported in included trials, in order to get uniform data and uniform combined outcome, this article analysed the frequency of spontaneous bowel movements (SBMs) per week and adverse events including cardiac complications. The combined outcomes following use of 1, 2, and $4 \mathrm{mg}$ doses of prucalopride is given in the following 6 subheadings. The short summary of resulting evidence is given in Figure 2 in tabulated form.

\section{Spontaneous Bowel Movements per Week After Use of $1 \mathrm{mg}$ Prucalopride Versus Placebo}

Five included trials (Fig. 3) contributed to the combined calculation of this variable. There was no heterogeneity $\left(\mathrm{Tau}^{2}=0.00\right.$; $\left.\mathrm{Chi}^{2}=2.84, \mathrm{df}=4[P=0.590] ; \mathrm{I}^{2}=0 \%\right)$ among the trials. In the random effects model (SMD, 0.42; 95\% CI, 0.18-0.66; z $=3.44 ; P<0.0006$ ), there was a higher risk of reduced SBMs per week in the placebo group and subsequently the frequency of SBMs per week was higher following the use of $1 \mathrm{mg}$ prucalopride to treat chronic constipation.

\section{Adverse Events After Use of $1 \mathrm{mg}$ Prucalopride Versus Placebo}

The reported adverse events following the use of prucalopride included abdominal cramps, abdominal pain, nausea, vomiting, dizziness, diarrhea, rash, headache, constipation, skin disorders, and flatulence. Seven included trials (Fig. 4) contributed to the combined calculation of this variable. There was no heterogeneity ( $\mathrm{Tau}^{2}$ $\left.=0.15 ; \mathrm{Chi}^{2}=7.70, \mathrm{df}=6[P=0.260] ; \mathrm{I}^{2}=22 \%\right)$ among the trials. In the random effects model (OR, 2.02; 95\% CI, 1.10-3.72;

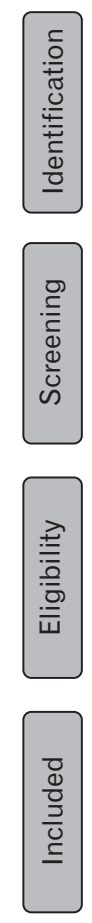

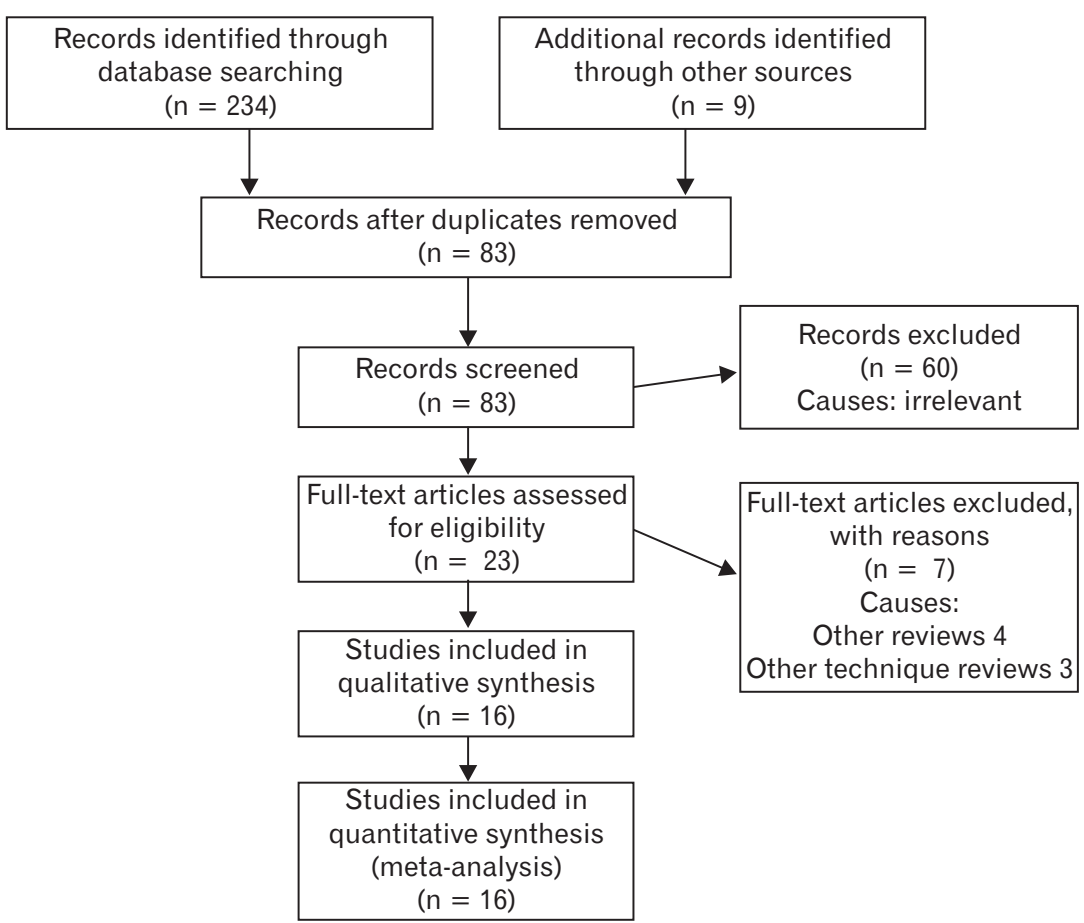

Figure 1. Preferred Reporting Items for Systematic Reviews and MetaAnalyses (PRISMA) flow chart to show study selection. 
Table. Characteristics of Included Trials

\begin{tabular}{|c|c|c|c|c|c|}
\hline Study & Year & Country & Patients & $\begin{array}{l}\text { Comparison } \\
\text { Groups }\end{array}$ & $\begin{array}{l}\text { Investigated } \\
\text { Variables }\end{array}$ \\
\hline Bouras et $\mathrm{al}^{43}$ & 1999 & USA & 50 & $\begin{array}{l}0.5 \mathrm{mg} \text { vs placebo } \\
1 \mathrm{mg} \text { vs placebo } \\
2 \mathrm{mg} \text { vs placebo }\end{array}$ & Colonic transit time \\
\hline Bouras et $\mathrm{al}^{44}$ & 2001 & USA & 40 & $\begin{array}{l}2 \mathrm{mg} \text { vs placebo } \\
4 \mathrm{mg} \text { vs placebo }\end{array}$ & $\begin{array}{l}\text { Colonic transit time, gastric emptying, small bowel transit } \\
\text { time }\end{array}$ \\
\hline Camilleri et $\mathrm{al}^{45}$ & 2008 & USA, Belgium & 620 & $\begin{array}{l}2 \mathrm{mg} \text { vs placebo } \\
4 \mathrm{mg} \text { vs placebo }\end{array}$ & $\begin{array}{l}\text { Spontaneous bowel movement per week and HR-QOL } \\
\text { measurement and safety }\end{array}$ \\
\hline Camilleri et $\mathrm{al}^{46}$ & 2009 & USA & 89 & $\begin{array}{l}0.5 \mathrm{mg} \text { vs placebo } \\
1 \mathrm{mg} \text { vs placebo } \\
2 \mathrm{mg} \text { vs placebo }\end{array}$ & $\begin{array}{l}\text { Adverse events, ECG changes, Holter monitor, pharmaco- } \\
\text { kinetics. }\end{array}$ \\
\hline Coremans et $\mathrm{al}^{47}$ & 2003 & Belgium & 55 & $4 \mathrm{mg}$ vs placebo & $\begin{array}{l}\text { Efficacy using VAS, complications, bowel function, transit } \\
\text { time }\end{array}$ \\
\hline Emmanuel et $\mathrm{al}^{48}$ & 2002 & UK & 74 & $1 \mathrm{mg}$ vs placebo & $\begin{array}{l}\text { Oro-caecal transit time, visceral sensitivity, HR-QOL and } \\
\text { psychological state }\end{array}$ \\
\hline Ke et $\mathrm{al}^{49}$ & 2012 & Asia-Pacific region & 501 & $2 \mathrm{mg}$ vs placebo & $\begin{array}{l}\text { Spontaneous bowel movement per week, safety and adverse } \\
\text { events }\end{array}$ \\
\hline Krogh et $\mathrm{al}^{50}$ & 2002 & Denmark & 16 & $\begin{array}{l}1 \mathrm{mg} \text { vs placebo } \\
2 \mathrm{mg} \text { vs placebo }\end{array}$ & Transit time, efficacy, bowel function \\
\hline Mugie et $\mathrm{al}^{51}$ & 2014 & Multicenter & 213 & $2 \mathrm{mg}$ vs placebo & $\begin{array}{l}\text { Spontaneous bowel movement per week and HR-QOL } \\
\text { measurement }\end{array}$ \\
\hline Muller-Nissler et $\mathrm{al}^{52}$ & 2010 & Germany & 300 & $\begin{array}{l}1 \mathrm{mg} \text { vs placebo } \\
2 \mathrm{mg} \text { vs placebo } \\
4 \mathrm{mg} \text { vs placebo }\end{array}$ & $\begin{array}{l}\text { Spontaneous bowel movement per week, frequency of bowel } \\
\text { movement, safety, tolerability, HR-QOL for constipation }\end{array}$ \\
\hline Poen et $\mathrm{al}^{53}$ & 1999 & Netherlands & 24 & $\begin{array}{l}1 \mathrm{mg} \text { vs placebo } \\
2 \mathrm{mg} \text { vs placebo }\end{array}$ & $\begin{array}{l}\text { Total transit time, mean transit time and anorectal physiol- } \\
\text { ogy studies }\end{array}$ \\
\hline Quigley et $\mathrm{al}^{54}$ & 2009 & Ireland & 641 & $\begin{array}{l}2 \mathrm{mg} \text { vs placebo } \\
4 \mathrm{mg} \text { vs placebo }\end{array}$ & $\begin{array}{l}\text { Spontaneous bowel movement per week and HR-QOL } \\
\text { measurement and tolerability }\end{array}$ \\
\hline Sloots et $\mathrm{al}^{55}$ & 2002 & Netherlands & 37 & $\begin{array}{l}1 \mathrm{mg} \text { vs placebo } \\
2 \mathrm{mg} \text { vs placebo }\end{array}$ & $\begin{array}{l}\text { Anorectal physiological study, bowel diary, transit time and } \\
\text { rectal compliance/sensitivity }\end{array}$ \\
\hline Sloots et $\mathrm{al}^{56}$ & 2010 & Netherlands & 196 & $\begin{array}{l}2 \mathrm{mg} \text { vs placebo } \\
4 \mathrm{mg} \text { vs placebo }\end{array}$ & $\begin{array}{l}\text { Spontaneous bowel movement per week, safety and adverse } \\
\text { events }\end{array}$ \\
\hline Tack et $\mathrm{al}^{57}$ & 2009 & Belgium & 713 & $\begin{array}{l}2 \mathrm{mg} \text { vs placebo } \\
4 \mathrm{mg} \text { vs placebo }\end{array}$ & $\begin{array}{l}\text { Spontaneous bowel movement per week and HR-QOL } \\
\text { measurement }\end{array}$ \\
\hline Yiannakou et $\mathrm{al}^{58}$ & 2015 & Multicenter & 374 & $2 \mathrm{mg}$ vs placebo & $\begin{array}{l}\text { HR-QOL, constipation severity, spontaneous bowel move- } \\
\text { ments per week }\end{array}$ \\
\hline
\end{tabular}

HR-QOL, Health related quality of life; ECG, electrocardiogram; VAS, visual analogue scale.

$z=2.26 ; P=0.020)$, the risk of developing the above mentioned adverse events was higher in the prucalopride group which in fewer cases, lead to the discontinuation of the treatment. A negligible number of patients were non-responders to prucalopride after 2 weeks of therapy and in those cases treatment was discontinued.

\section{Spontaneous Bowel Movements per Week After Use of $2 \mathrm{mg}$ Prucalopride Versus Placebo}

Nine included trials (Fig. 5) contributed to the combined calculation of this variable. There was significant heterogeneity $\left(\mathrm{Tau}^{2}=0.07 ; \mathrm{Chi}^{2}=36.40, \mathrm{df}=8[P=0.0001] ; \mathrm{I}^{2}=78 \%\right)$ among the trials. In the random effects model (SMD, 0.34; $95 \%$ CI, 0.11-0.56; $\mathrm{z}=2.94 ; P=0.003)$, there was a higher risk of reduced SBMs per week in the placebo group and subsequently the frequency of SBMs per week was higher following the use of $2 \mathrm{mg}$ prucalopride to treat chronic constipation. 


\begin{tabular}{|c|c|c|c|c|c|}
\hline \multicolumn{6}{|c|}{ Prucalopride $1 \mathrm{mg}$ versus placebo for chronic constipation } \\
\hline \multicolumn{6}{|c|}{$\begin{array}{l}\text { Patient or population: patients with chronic constipation } \\
\text { Settings: } \\
\text { Intervention: prucalopride } 1 \mathrm{mg} \text { versus placebo }\end{array}$} \\
\hline \multirow[t]{3}{*}{ Outcomes } & Illustrative comparative risks* $(95 \% \mathrm{Cl})$ & \multirow{3}{*}{$\begin{array}{l}\text { Relative effect } \\
(95 \% \mathrm{Cl})\end{array}$} & \multirow{3}{*}{$\begin{array}{l}\text { No of Participants } \\
\text { (studies) }\end{array}$} & \multirow{3}{*}{$\begin{array}{l}\text { Quality of the } \\
\text { evidence } \\
\text { (GRADE) }\end{array}$} & \multirow[t]{3}{*}{ Comments } \\
\hline & Assumed risk Corresponding risk & & & & \\
\hline & Prucalopride $1 \mathrm{mg}$ versus placebo & & & & \\
\hline $\begin{array}{l}\text { Risk of reduced SBM per } \\
\text { week } \\
\text { Standardized mean difference } \\
\text { Follow-up: } 1-12 \text { weeks } \\
\end{array}$ & $\begin{array}{l}\text { The mean risk of reduced SBM per week in the intervention } \\
\text { groups was } \\
0.42 \text { standard deviations higher } \\
\text { ( } 0.18 \text { to } 0.66 \text { higher) }\end{array}$ & & $\begin{array}{l}277 \\
\text { (5 studies) }\end{array}$ & $\begin{array}{l}\bigoplus \oplus \oplus \oplus \\
\text { high }\end{array}$ & SMD $0.42(0.18$ to 0.66$)$ \\
\hline \multirow{4}{*}{$\begin{array}{l}\text { Complications } \\
\text { Odds ratio } \\
\text { Follow-up: } 1-12 \text { weeks }\end{array}$} & \multirow{2}{*}{$\begin{array}{r}\text { Study population } \\
512 \text { per } 1,000680 \text { per } 1,000 \\
\text { (536 or } 796)\end{array}$} & \multirow{4}{*}{$\begin{array}{l}\text { OR } 2.02 \\
\text { (1.1 to } 3.72)\end{array}$} & \multirow{4}{*}{$\begin{array}{l}337 \\
\text { (7 studies) }\end{array}$} & \multirow{4}{*}{$\begin{array}{l}\oplus \oplus \oplus \oplus \\
\text { high }\end{array}$} & \\
\hline & & & & & \\
\hline & Moderate & & & & \\
\hline & $\begin{array}{r}500 \text { per } 1,000669 \text { per } 1,000 \\
\text { (524 or } 788 \text { ) }\end{array}$ & & & & \\
\hline \multicolumn{6}{|c|}{ Prucalopride $2 \mathrm{mg}$ versus placebo for chronic constipation } \\
\hline \multicolumn{6}{|c|}{$\begin{array}{l}\text { Patient or population: patients with chronic constipation } \\
\text { Settings: } \\
\text { Intervention: prucalopride } 2 \mathrm{mg} \text { versus placebo }\end{array}$} \\
\hline \multirow[t]{2}{*}{ Outcomes } & Illustrative comparative risks ${ }^{*}(95 \% \mathrm{Cl})$ & \multirow{2}{*}{$\begin{array}{l}\text { Relative effect } \\
(95 \% \mathrm{CI})\end{array}$} & \multirow{2}{*}{$\begin{array}{l}\text { No of Participants } \\
\text { (studies) }\end{array}$} & \multirow{2}{*}{$\begin{array}{l}\text { Quality of the } \\
\text { evidence } \\
\text { (GRADE) }\end{array}$} & \multirow[t]{2}{*}{ Comments } \\
\hline & Assumed risk Corresponding risk & & & & \\
\hline $\begin{array}{l}\text { Risk of reduced SBM per } \\
\text { week } \\
\text { Standardized mean difference } \\
\text { Follow-up: } 1 \text {-12 weeks } \\
\end{array}$ & $\begin{array}{l}\text { The mean risk of reduced SBM per week in the intervention } \\
\text { groups was } \\
0.34 \text { standard deviations higher } \\
\text { ( } 0.11 \text { to } 0.56 \text { higher) }\end{array}$ & & $\begin{array}{l}1962 \\
\text { (9 studies) }\end{array}$ & $\begin{array}{l}\oplus \oplus \oplus \oplus \\
\text { high }\end{array}$ & SMD 0.34 (0.11 to 0.56$)$ \\
\hline \multirow{3}{*}{$\begin{array}{l}\text { Complications } \\
\text { Odds ratio } \\
\text { Follow-up: } 1 \text {-12 weeks }\end{array}$} & Study population & \multirow{3}{*}{$\begin{array}{l}\text { OR } 1.76 \\
(1.33 \text { to } 2.34)\end{array}$} & \multirow{3}{*}{$\begin{array}{l}2812 \\
\text { (13 studies) }\end{array}$} & \multirow{3}{*}{$\begin{array}{l}\oplus \oplus \oplus \oplus \\
\text { high }\end{array}$} & \\
\hline & $\begin{array}{r}475 \text { per } 1,000615 \text { per } 1,000 \\
(547 \text { or } 680) \\
\end{array}$ & & & & \\
\hline & Moderate & & & & \\
\hline \multicolumn{6}{|c|}{ Prucalopride $4 \mathrm{mg}$ versus placebo for chronic constipation } \\
\hline \multicolumn{6}{|c|}{$\begin{array}{l}\text { Patient or population: patients with chronic constipation } \\
\text { Settings: } \\
\text { Intervention: prucalopride } 4 \mathrm{mg} \text { versus placebo }\end{array}$} \\
\hline \multirow[t]{2}{*}{ Outcomes } & Illustrative comparative risks ${ }^{*}(95 \% \mathrm{Cl})$ & \multirow{2}{*}{$\begin{array}{l}\text { Relative effect } \\
(95 \% \mathrm{Cl})\end{array}$} & \multirow{2}{*}{$\begin{array}{l}\text { No of Participants } \\
\text { (studies) }\end{array}$} & \multirow{2}{*}{$\begin{array}{l}\text { Quality of the } \\
\text { evidence } \\
\text { (GRADE) }\end{array}$} & \multirow[t]{2}{*}{ Comments } \\
\hline & $\begin{array}{ll}\text { Assumed risk } & \text { Corresponding risk } \\
\text { Control } & \text { Prucalopride } 4 \mathrm{mg} \text { versus placebo }\end{array}$ & & & & \\
\hline $\begin{array}{l}\text { Risk of reduced SBM per } \\
\text { week } \\
\text { Standardized mean difference } \\
\text { Follow-up: } 1-12 \text { weeks } \\
\end{array}$ & $\begin{array}{l}\text { The mean risk of reduced SBM per week in the intervention } \\
\text { groups was } \\
0.33 \text { standard deviations higher } \\
\text { ( } 0.22 \text { to } 0.44 \text { higher) }\end{array}$ & & $\begin{array}{l}1240 \\
(5 \text { studies) }\end{array}$ & $\begin{array}{l}\bigoplus \bigoplus \bigoplus \oplus \\
\text { high }\end{array}$ & SMD $0.33(0.22$ to 0.44$)$ \\
\hline Complications & Study population & OR 1.52 & 1672 & & \\
\hline & $\begin{array}{r}637 \text { per } 1,000727 \text { per } 1,000 \\
(664 \text { or } 782)\end{array}$ & $(1.13$ to 2.05$)$ & (7) & & \\
\hline & Moderate & & & & \\
\hline & $\begin{array}{r}556 \text { per } 1,000656 \text { per } 1,000 \\
(586 \text { or } 720)\end{array}$ & & & & \\
\hline
\end{tabular}

Figure 2. GradePro quality of evidence summary. SBM, spontaneous bowel movement; SMD, standardized mean difference.

\section{Adverse Events After Use of $2 \mathrm{mg}$ Prucalopride Versus Placebo}

Thirteen included trials (Fig. 6) contributed to the combined calculation of this variable. There was significant heterogeneity $\left(\mathrm{Tau}^{2}=0.12 ; \mathrm{Chi}^{2}=25.44, \mathrm{df}=12[\mathrm{P}=0.010] ; \mathrm{I}^{2}=53 \%\right)$ among the trials. In the random effects model $(\mathrm{OR}, 1.76 ; 95 \% \mathrm{CI}$, 1.33-2.34; $z=3.92 ; P<0.0001)$, the risk of developing adverse events was higher in the prucalopride group which in fewer cases, lead to the discontinuation of the treatment. The trend of increased number of patients with adverse events was also noted following the use of $2 \mathrm{mg}$ prucalopride compared to $1 \mathrm{mg}$. A negligible number of patients were non-responders to prucalopride after 2 weeks of therapy and in those cases treatment was discontinued.

\section{Spontaneous Bowel Movements per Week After Use of $4 \mathrm{mg}$ Prucalopride Versus Placebo}

Five included trials (Fig. 7) contributed to the combined calculation of this variable. There was no heterogeneity $\left(\mathrm{Tau}^{2}=0.00\right.$; $\left.\mathrm{Chi}^{2}=0.65, \mathrm{df}=4[P=0.960] ; \mathrm{I}^{2}=0 \%\right)$ among the trials. In the random effects model (SMD, 0.33; 95\% CI, 0.22-0.44; $\mathrm{z}$ $=5.78 ; P<0.00001)$, there was a higher risk of reduced SBMs per week in the placebo group and subsequently the frequency of SBMs per week was higher following the use of $4 \mathrm{mg}$ prucalo- 


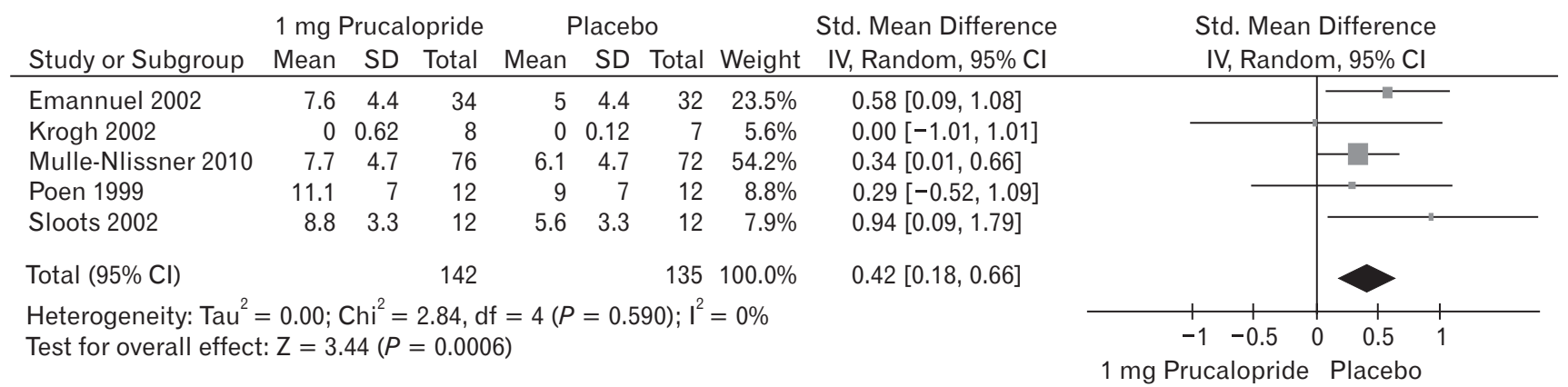

Figure 3. Forest plot for reduced spontaneous bowel movement after $1 \mathrm{mg}$ versus placebo in patients with chronic constipation. Combined outcome is expressed as standardized mean difference.

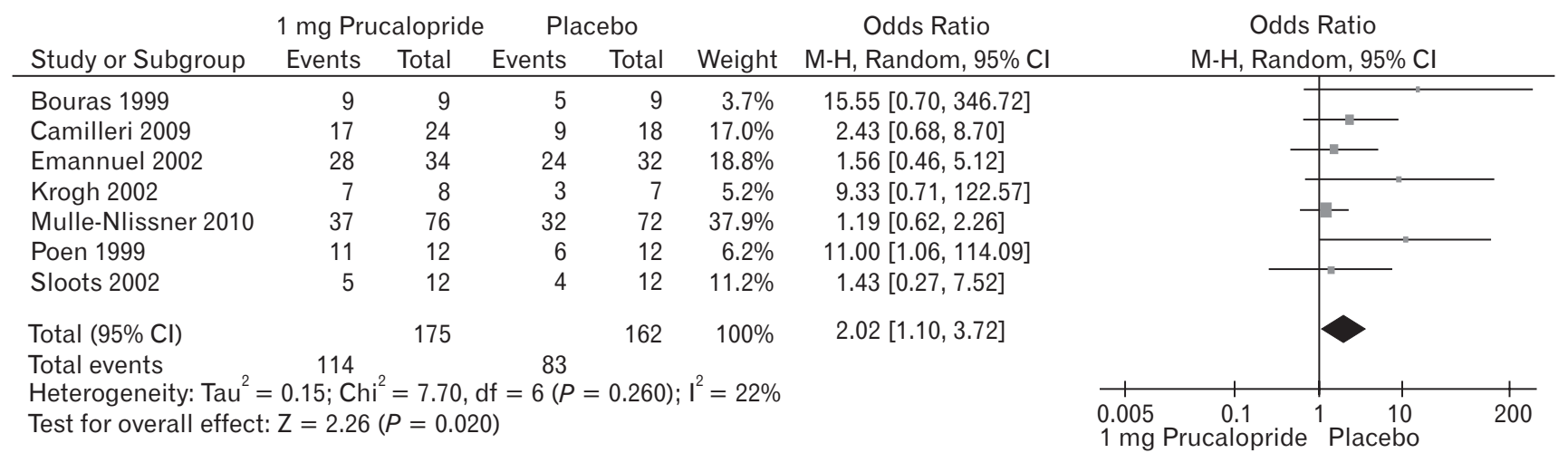

Figure 4. Forest plot for complications after $1 \mathrm{mg}$ versus placebo in patients with chronic constipation. Combined outcome is expressed as odds ratio.

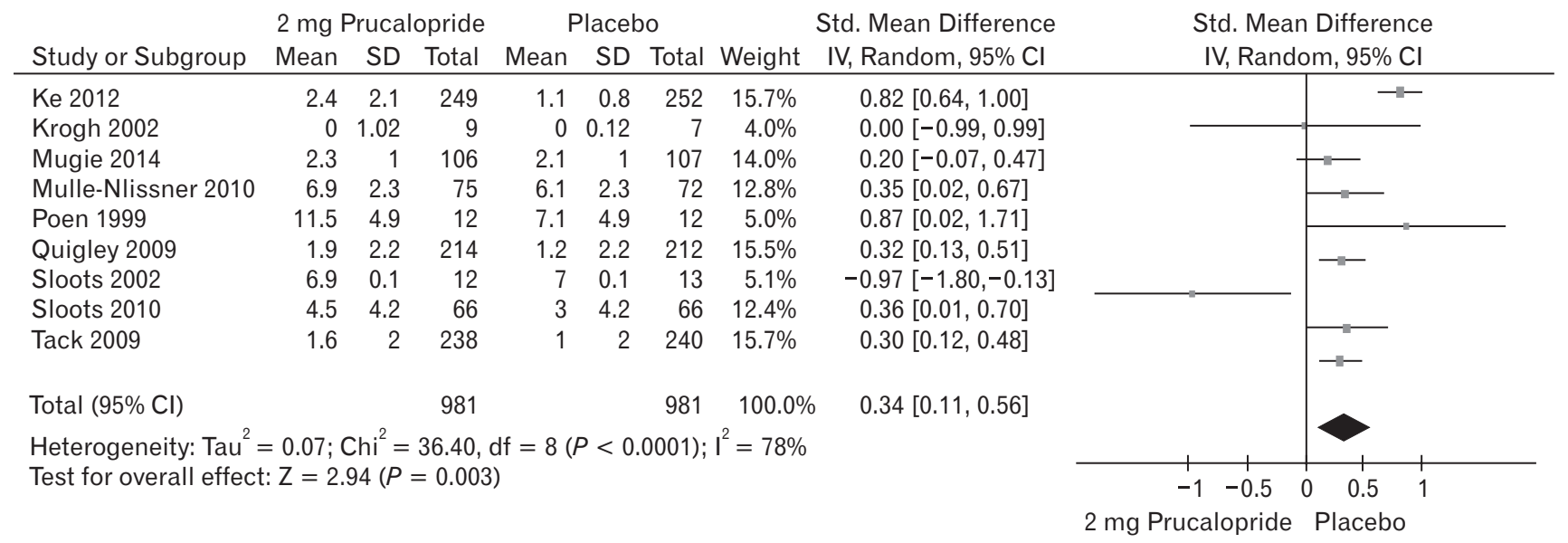

Figure 5. Forest plot for reduced spontaneous bowel movement after $2 \mathrm{mg}$ versus placebo in patients with chronic constipation. Combined outcome is expressed as standardized mean difference. 


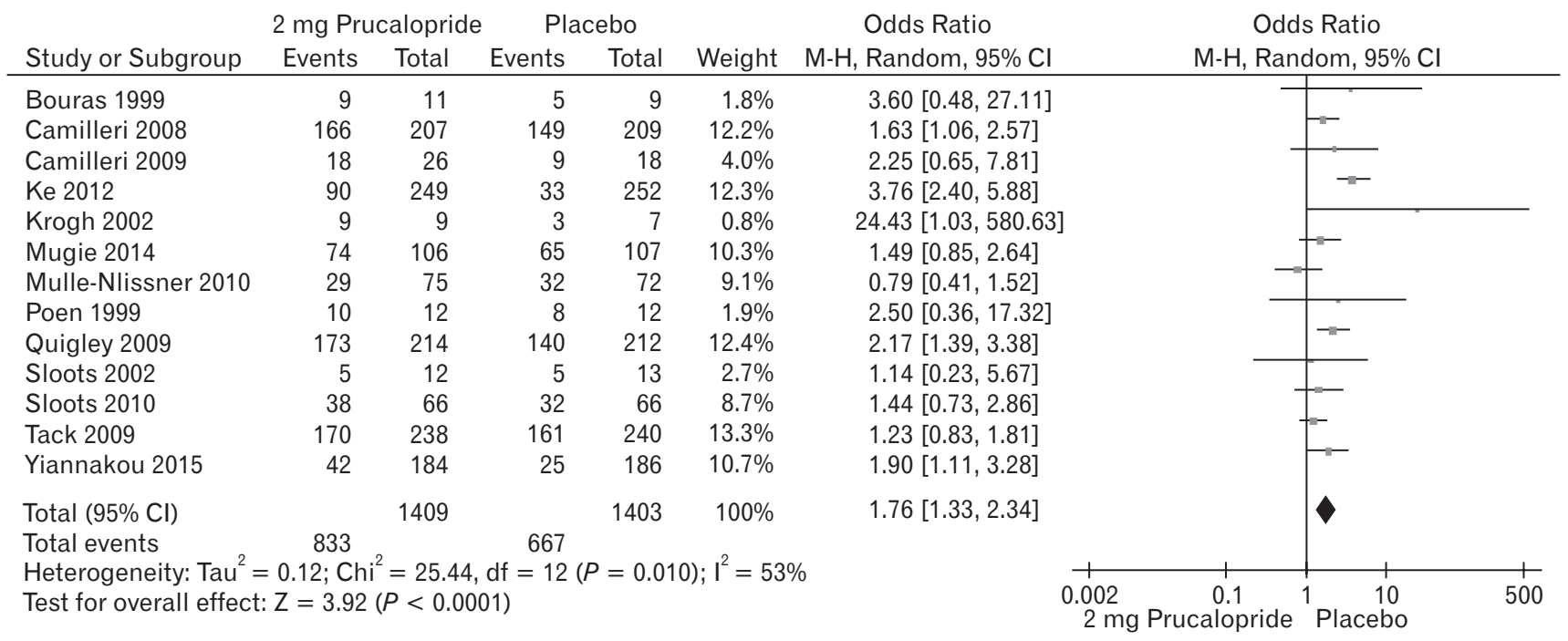

Figure 6. Forest plot for complications after $2 \mathrm{mg}$ versus placebo in patients with chronic constipation. Combined outcome is expressed as odds ratio.

\begin{tabular}{|c|c|c|c|c|c|c|c|c|c|c|c|}
\hline Study or Subgroup & \multicolumn{3}{|c|}{4 mg Prucalopride } & \multicolumn{3}{|c|}{ Placebo } & \multicolumn{2}{|c|}{$\begin{array}{c}\text { Std. Mean Difference } \\
\text { Weight } \quad \text { IV, Random, } 95 \% \mathrm{CI}\end{array}$} & \multicolumn{3}{|c|}{$\begin{array}{l}\text { Std. Mean Difference } \\
\text { IV, Random, } 95 \% \mathrm{Cl}\end{array}$} \\
\hline Coremans 2003 & 4.23 & 1.3 & 27 & 3.52 & 1.3 & 26 & $4.2 \%$ & $0.54[-0.01,1.09]$ & & & \\
\hline Mulle-Nlissner 2010 & 7.1 & 3 & 80 & 6.1 & 3 & 72 & $12.2 \%$ & $0.33[0.01,0.65]$ & & & \\
\hline Quigley 2009 & 2 & 2.5 & 215 & 1.2 & 2.5 & 212 & $34.5 \%$ & $0.32[0.13,0.51]$ & & $-1-$ & \\
\hline Sloots 2010 & 4.9 & 5.2 & 64 & 3 & 5.2 & 66 & $10.5 \%$ & $0.36[0.02,0.71]$ & & & \\
\hline Tack 2009 & 1.9 & 2.9 & 238 & 1 & 2.9 & 240 & $38.6 \%$ & $0.31[0.13,0.49]$ & & & \\
\hline Total $(95 \% \mathrm{Cl})$ & & & 624 & & & 616 & $100.0 \%$ & $0.33[0.22,0.44]$ & & & \\
\hline $\begin{array}{l}\text { Heterogeneity: } \text { Tau }^{2}= \\
\text { Test for overall effect }\end{array}$ & $\begin{array}{l}=0.00 \\
: Z=5\end{array}$ & $i^{2}=$ & $\begin{array}{l}65, d t \\
0.000\end{array}$ & $=4($ & & $0) ; 1^{2}$ & $=0 \%$ & & $\begin{array}{ll}-1 & -0.5 \\
4 \mathrm{mg} \text { Prucalopride }\end{array}$ & 0.5 & 1 \\
\hline
\end{tabular}

Figure 7. Forest plot for reduced spontaneous bowel movement after $4 \mathrm{mg}$ versus placebo in patients with chronic constipation. Combined outcome is expressed as standardized mean difference.

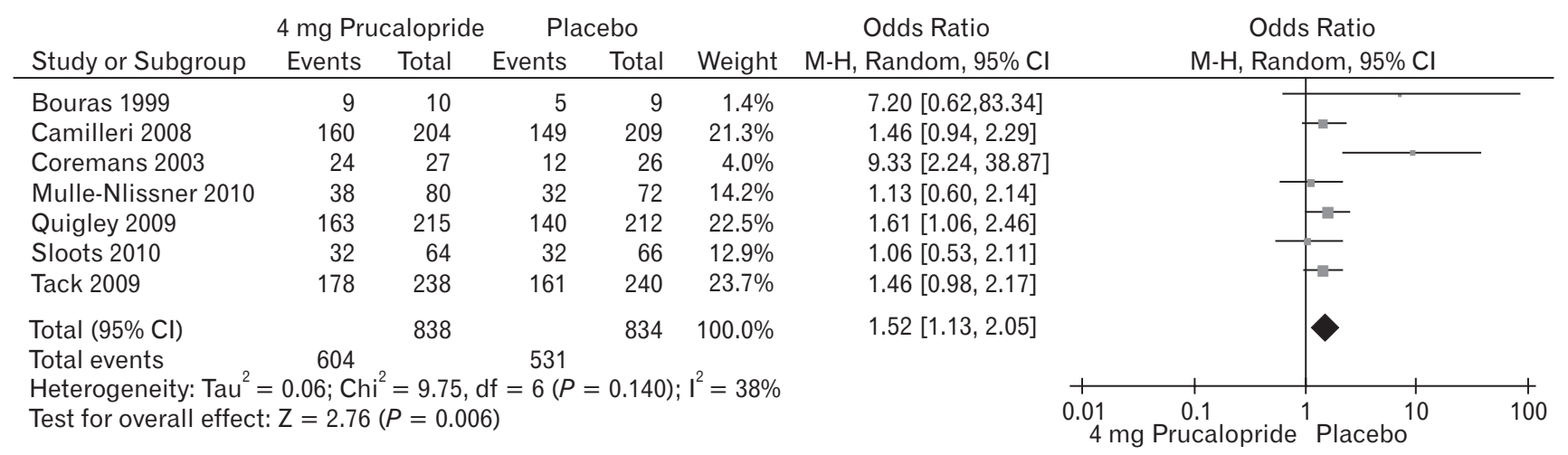

Figure 8. Forest plot for complications after $4 \mathrm{mg}$ versus placebo in patients with chronic constipation. Combined outcome is expressed as odds ratio. 
pride to treat chronic constipation. The SBM profile represented as SMD of 1,2, and $4 \mathrm{mg}$ doses of prucalopride in patients with chronic constipation were $0.42,0.34$, and 0.33 respectively indicating proportional effectiveness of higher doses of prucalopride.

\section{Adverse Events After Use of $4 \mathrm{mg}$ Prucalopride Versus Placebo}

Seven included trials (Fig. 8) contributed to the combined calculation of this variable. There was significant heterogeneity ( $\mathrm{Tau}^{2}$ $\left.=0.06 ; \mathrm{Chi}^{2}=9.75 ; \mathrm{df}=6[P=0.14] ; \mathrm{I}^{2}=38 \%\right)$ among the trials. In the random effects model $(\mathrm{OR}, 1.52 ; 95 \% \mathrm{CI}, 1.13-2.05$; $z=2.76 ; P=0.006$ ), the risk of developing adverse events was higher in the prucalopride group which in fewer cases lead to the discontinuation of the treatment. The trend of increased number of patients with adverse events was also noted following the use of 4 $\mathrm{mg}$ prucalopride compared to $1 \mathrm{mg}$ and $2 \mathrm{mg}$. A negligible number of patients were non-responders to prucalopride after 2 weeks of therapy, and in those cases treatment was discontinued. The adverse events profile represented as OR of 1,2, and $4 \mathrm{mg}$ doses of prucalopride in patients with chronic constipation were 2.02, 1.76, and 1.52 , respectively indicating proportional effectiveness of prucalopride without causing increased side effects.

\section{Discussion}

To the best of our knowledge the results of this largest ever meta-analysis on 16 high-quality randomized, controlled trials published in peer review journals on 3943 patients demonstrate that prucalopride is an effective pharmacotherapy in the management of chronic constipation with acceptable, transient, and negligible side effects.

The findings of the current study are pertinent to only that group of patients which have failed basic laxative therapy (lactulose, ispaghula husk, and senna), life style modifications and stronger laxatives therapy (macrogol, bisacodyl or glycerol suppository, sodium phosphate, and arachis oil enema), and therefore, conclusion cannot be generalized to all types of constipation and on group of patients where early treatment is not optimally tested. However, there are several systematic reviews and meta-analyses evaluating the role of prucalopride ${ }^{59-68}$ in the management of chronic constipation and their findings are consistent with the findings of the current study. Although the scope of the current article is the evaluation of clinical effectiveness and adverse events related to prucalopride only, previously reported systematic reviews ${ }^{59-68}$ have reported its safety, efficacy, pharmacokinetics, and tolerability providing supporting evidence to our conclusions. As reported by Tack et al ${ }^{69}$ "Prucalopride is an important addition to the therapeutic abilities for treating chronic constipation, especially in females poorly responding to laxatives. The safety profile of the drug, to date, is favorable. There is also the possibility that prucalopride might be of benefit to other disorders of gastrointestinal motility with a number of studies currently in progress, which are evaluating alternative applications".

This study reports a total of 3943 participants from 16 randomized, controlled trials undergoing prucalopride therapy for chronic constipation. The risk of bias in the included trials was low when scored against the standard quality guidelines, and therefore, the quality of the resulting evidence may be considered adequate. However, the potential limitations of this study and evidence include different inclusion and exclusion criteria, combined analysis of phase II and phase III trials, variable primary and secondary outcomes, variable duration of prucalopride therapy and variable duration of follow-up among included randomized, controlled trials.

The reported procedure of statistical examination, included study value scoring and overall worthiness of resulting evidence was evaluated according to the recommendations of the Cochrane Collaboration. The reasons of being reduced possibility of biased can be categorized as cited in the included studies are the existence of blinding, allocation concealment. The reporting of acceptable randomization procedure and optimal employment of the power calculations in studies resulted in the provision of satisfactory power to create stronger evidence in favor of current article. The aforementioned methodological limitations should be acknowledged while accepting the conclusions of this study.

The findings of the current meta-analysis on 16 randomized, controlled trials are in accordance with the conclusions of previously published reviews. ${ }^{59-67}$ However, this study provides up to date, comprehensive and cumulative evidence on the use of prucalopride that meaningfully reduce symptoms related to chronic constipation. One review ${ }^{59}$ reported the combined analysis of 3 trials, 4 reviews $^{62,64,65,67}$ reported the combined analysis of 4 trials each, 2 reviews $^{64,66}$ reported systematic review of the trials evaluating four $5-\mathrm{HT}_{4}$ agonist agents, whereas 3 reviews $^{60,61,68}$ were evidence reviews.

The most commonly reported adverse events following prucalopride therapy for chronic constipation are headache (25-30\% prucalopride versus $12-17 \%$ placebo), nausea (12-24\% versus $8-14 \%$ ), abdominal pain or cramps (16-23\% versus 11-19\%), and diarrhea (12-19\% versus $3-5 \%){ }^{45,46,54,57,63,65}$ The majority of these adverse events were experienced by the study group within the first 24 hours of the commencement of prucalopride therapy and were short 
lived. ${ }^{54}$ When reported, the incidence of serious adverse events was statistically similar for placebo and prucalopride groups. ${ }^{45,46,54,57,63,65}$ Like other $5-\mathrm{HT}_{4}$ agonists such as cisapride, there were concerns about the risk of cardiac side effects after the use of prucalopride because prucalopride has not been found to interact with either the human ether-à-go-go-related gene ( $h E R G$ ) potassium channel (responsible for cisapride-induced arrhythmias) or $5-\mathrm{HT}_{1 \mathrm{~B}}$ receptors (mechanism behind tegaserod induced side effects), both assumed to be responsible for the bradycardia and cardiovascular adverse events. ${ }^{45,46,51,56,57,59,63,69}$ In a similar study evaluating the cardiovascular safety profile of prucalopride in a relatively high-risk population of old-age care home patients with $80 \%$ having a prior history of cardiovascular disease, no significant hemodynamic or electrocardiographic changes were reported. Explicitly, there was no increased incidence of prolongation of the QT interval or bradycardia in the prucalopride group compared to placebo. ${ }^{45,46}$

Prucalopride seems to be effective for the management of chronic constipation resistant to conventional laxatives. However, generalizing the outcomes of the current study to every type of patient will be unrealistic. After careful exclusion of secondary causes of constipation, prucalopride may be prescribed to the majority of the patients presenting with chronic constipation. Further studies on a particular group of patients such as normal transit constipation and slow transit constipation are mandatory to define which group of the patients may benefit more from the prucalopride therapy. In addition, in patients with psychiatric and psychological disorders while on multiple antidepressants or anti-psychotics, the role of prucalopride needs further evaluation due to its potential to activate $5-\mathrm{HT}_{4}$ receptors. Patients with pelvis floor disorders and obstructive defecation syndrome following pelvic floor exercises or surgical intervention may still need assistance in bowel evacuation. The question still remains to be answered is whether prucalopride can still be used in these groups of patients if conventional laxatives fail to provide symptomatic relief. There are several published studies on the pharmacokinetics of prucalopride but trials in the elderly population are scarce where the incidence of chronic constipation is prevalent, and they usually have associated cardiac, renal, liver, and lung co-morbidities. The safety, tolerability, and clinical effectiveness in the elderly population need further evaluation prior to the routine use of prucalopride therapy for conventional laxativeresistant chronic constipation.

\section{Financial support: None.}

\section{Conflicts of interest: None.}

Author contributions: Muhammad S Sajid, Madhu Hebbar, Mirza K Baig, Andy Li, and Zinu Philiposere equally involved and equally contributed into the study design, study conduction, and drafting the manuscript.

\section{References}

1. Longstreth GF, Thompson WG, Chey WD, Houghton LA, Mearin F, Spiller RC. Functional bowel disorders. Gastroenterology 2006;130: 1480-1491.

2. Drossman DA, Dumitrascu DL. Rome III: New standard for functional gastrointestinal disorders. J Gastrointestin Liver Dis 2006;15:237-241.

3. Sonnenberg A, Koch TR. Epidemiology of constipation in the United States. Dis Colon Rectum 1989;32:1-8.

4. Locke GR 3rd, Pemberton JH, Phillips SF. AGA technical review on constipation. American Gastroenterological Association. Gastroenterology 2000;119:1766-1778.

5. Müller-Lissner SA. Effect of wheat bran on weight of stool and gastrointestinal transit time: a meta analysis. Br Med J (Clin Res Ed) 1988;296:615-617.

6. Petticrew M, Rodgers M, Booth A. Effectiveness of laxatives in adults. Qual Health Care 2001;10:268-273.

7. Borum ML. Constipation: evaluation and management. Prim Care 2001;28:577-590, vi.

8. Chaussade S, Minić M. Comparison of efficacy and safety of two doses of two different polyethylene glycol-based laxatives in the treatment of constipation. Aliment Pharmacol Ther 2003;17:165-172.

9. Bouhnik Y, Neut C, Raskine L, et al. Prospective, randomized, parallelgroup trial to evaluate the effects of lactulose and polyethylene glycol-4000 on colonic flora in chronic idiopathic constipation. Aliment Pharmacol Ther 2004;19:889-899.

10. Attar A, Lémann M, Ferguson A, et al. Comparison of a low dose polyethylene glycol electrolyte solution with lactulose for treatment of chronic constipation. Gut 1999;44:226-230.

11. Cleveland MV, Flavin DP, Ruben RA, Epstein RM, Clark GE. New polyethylene glycol laxative for treatment of constipation in adults: a randomized, double-blind, placebo-controlled study. South Med J 2001;94:478-481.

12. Corazziari E, Badiali D, Bazzocchi G, et al. Long term efficacy, safety, and tolerability of low daily doses of isosmotic polyethylene glycol electrolyte balanced solution (PMF-100) in the treatment of functional chronic constipation. Gut 2000;46:522-526.

13. MiraLax polyethylene glycol 3550, NF powder for solution. Braintree Laboratories, Inc. Available from URL: http://www.drugs.com/cdi/ polyethylene-glycol-3350-powder-for-oral-solution.html (accessed 21 April 2016).

14. Ramkumar D, Rao SSC. Efficacy and safety of traditional medical therapies for chronic constipation: systematic review. Am J Gastroenterol 
2005;100:936-971.

15. Muller-Lissner SA, Kamm MA, Scarpignato C, Wald A. Myths and misconceptions about chronic constipation. Am J Gastroenterol 2005;100:232-242.

16. Shafik A, Shafik AA, el-Sibai O, Ahmed I. Colonic pacing in patients with constipation due to colonic inertia. Med Sci Monit 2003;9:CR243CR248.

17. Kenefick NJ, Vaizey CJ, Cohen CRG, Nicholls RJ, Kamm MA. Double-blind placebo-controlled crossover study of sacral nerve stimulation for idiopathic constipation. Br J Surg 2002;89:1570-1571.

18. Chang HS, Myung SJ, Yang SK, et al. Effect of electrical stimulation in constipated patients with impaired rectal sensation. Int J Colorectal Dis 2003;18:433-438.

19. Drossman DA, Toner BB, Whitehead WE, et al. Cognitive-behavioral therapy versus education and desipramine versus placebo for moderate to severe functional bowel disorders. Gastroenterology 2003;125:19-31.

20. Heymen S, Wexner SD, Vickers D, Nogueras JJ, Weiss EG, Pikarsky AJ. Prospective, randomized trial comparing four biofeedback techniques for patients with constipation. Dis Colon Rectum 1999;42:1388-1393.

21. Heymen S, Jones KR, Scarlett Y, Whitehead WE. Biofeedback treatment of constipation: a critical review. Dis Colon Rectum 2003;46:12081217.

22. Altabas K, Bilić A, Jurcić $\mathrm{D}$, et al. The efficacy of cisapride vs. placebo and diet in patients with chronic constipation. Coll Antropol 2003;27:197204.

23. Johanson JF, Wald A, Tougas G, et al. Effect of tegaserod in chronic constipation: a randomized, double-blind, controlled trial. Clin Gastroenterol Hepatol 2004;2:796-805.

24. Johanson JF. Review article: tegaserod for chronic constipation. Aliment Pharmacol Ther 2004;20(suppl 7):20-24.

25. Kamm MA, Müller-Lissner S, Talley NJ, et al. Tegaserod for the treatment of chronic constipation: a randomized, double-blind, placebocontrolled multinational study. Am J Gastroenterol 2005;100:362-372.

26. Cash BD, Lacy BE. Systematic review: FDA-approved prescription medications for adults with constipation. Gastroenterol Hepatol 2006;2:736-749

27. Orr KK. Lubiprostone: a novel chloride channel activator for the treatment of constipation. Formulary 2006;41:118-120.

28. Winpenney JP. Lubiprostone. I Drugs 2005;8:416-422.

29. Johanson JF, Gargano MA, Holland PC, Patchen ML, Ueno R. Phase III study of lubiprostone, a chloride channel-2 (CIC-2) activator for the treatment of constipation: safety and primary efficacy. Am J Gastroenterol 2005;100(suppl 9s):A896.

30. Johanson JF, Gargano MA, Holland PC, Patchen ML, Ueno R. Initial and sustained effects of lubiprostone, a chloride channel-2 (CIC-2) activator for the treatment of constipation: data from a 4-week phase III study. Am J Gastroenterol 2005; 100(suppl 9s): A884.

31. Johanson JF, Gargano MA, Holland PC, Patchen ML, Ueno R. Phase III efficacy and safety of RU-0211, a novel chloride channel activator, for the treatment of constipation. Gastroenterology 2003;124(suppl 1):A48.

32. Johanson JF, Gargano MA, Holland PC, Patchen ML, Ueno R. Phase III, randomized withdrawal study of RU-0211, a novel chloride channel activator for the treatment of constipation. Gastroenterology 2004;126(suppl 2):A100.

33. Higgins JPT, Green S. Cochrane Handbook for Systematic Reviews of Interventions version 5.1.0 [updated March 2011]. The Cochrane Collaboration, 2011. Available from URL: http:/handbook.cochrane.org/ (accessed 21 April 2016).

34. Review Manager (Rev Man) [Computer program]. Version 5.0. The Nordic Cochrane Centre, The Cochrane Collaboration: Copenhagen, 2008. Available from URL: http://tech.cochrane.org/revman/download/ windows64 (accessed 21 April 2016).

35. DerSimonian R, Laird N. Meta-analysis in clinical trials. Control Clin Trials 1986;7:177-188.

36. Demets DL. Methods for combining randomized clinical trials: strengths and limitations. Stat Med 1987;6:341-350.

37. Higgins JP, Thompson SG. Quantifying heterogeneity in a meta-analysis. Stat Med 2002; 21:1539-1558.

38. Egger M, Smith GD, Altman DG. Systematic reviews in healthcare: meta-analysis in context. 2nd ed. London: BMJ Publication group 2001.

39. Egger M, Smith GD, Altman DG. Systemic reviews in health care: meta-analysis in context. 2nd ed. In: Deeks JJ, Altman DG, eds. Statistical methods for examining heterogeneity and combining results from several studies in meta-analysis. London: BMJ Publication group 2001:285312.

40. Jadad AR, Moore RA, Carroll D, et al. Assessing the quality of reports of randomized clinical trials: is blinding necessary? Control Clin Trials 1996;17:1-12.

41. Chalmers TC, Smith H, Blackburn B, et al. A method for assessing the quality of a randomized control trial. Control Clin Trials 1981;2:31-49.

42. Cochrane IMS. Available from: URL: http://ims.cochrane.org/revman/ other-resources/gradepro/download (accessed 21 April 2016).

43. Bouras EP, Camilleri M, Burton DD, McKinzie S. Selective stimulation of colonic transit by the benzofuran $5-\mathrm{HT}_{4}$ agonist, prucalopride, in healthy humans. Gut 1999;44:682-686.

44. Bouras EP, Camilleri M, Burton DD, Thomforde G, McKinzie S, Zinsmeister AR. Prucalopride accelerates gastrointestinal and colonic transit in patients with constipation without a rectal evacuation disorder. Gastroenterology 2001;120:354-360.

45. Camilleri M, Kerstens R, Rykx A, Vandeplassche L. A placebocontrolled trial of prucalopride for severe chronic constipation. N Engl J Med 2008;358:2344-2354.

46. Camilleri M, Beyens G, Kerstens R, Robinson P, Vandeplassche L. Safety assessment of prucalopride in elderly patients with constipation: a doubleblind, placebo-controlled study. Neurogastroenterol Motil 2009;21:1256e117.

47. Coremans G, Kerstens R, De Pauw M, Stevens M. Prucalopride is effective in patients with severe chronic constipation in whom laxatives fail to provide adequate relief. Results of a double-blind, placebo-controlled clinical trial. Digestion 2003;67:82-89.

48. Emmanuel AV, Roy AJ, Nicholls TJ, Kamm MA. Prucalopride, a systemic enterokinetic, for the treatment of constipation. Aliment Pharmacol Ther 2002;16:1347-1356.

49. Ke M, Zou D, Yuan Y, et al. Prucalopride in the treatment of chronic 
constipation in patients from the Asia-Pacific region: a randomized, double-blind, placebo-controlled study. Neurogastroenterol Motil 2012; 24:999-e541.

50. Krogh K, Jensen MB, Gandrup P, et al. Efficacy and tolerability of prucalopride in patients with constipation due to spinal cord injury. Scand J Gastroenterol 2002;37:431-436.

51. Mugie SM, Korczowski B, Bodi P, et al. Prucalopride is no more effective than placebo for children with functional constipation. Gastroenterology 2014;147:1285-1295.

52. Müller-Lissner S, Rykx A, Kerstens R, Vandeplassche L. A doubleblind, placebo-controlled study of prucalopride in elderly patients with chronic constipation. Neurogastroenterol Motil 2010;22:991-998.

53. Poen AC, Felt-Bersma RJ, Van Dongen PA, Meuwissen SG. Effect of prucalopride, a new enterokinetic agent, on gastrointestinal transit and anorectal function in healthy volunteers. Aliment Pharmacol Ther 1999;13:1493-1497.

54. Quigley EM, Vandeplassche L, Kerstens R, Ausma J. Clinical trial: the efficacy, impact on quality of life, and safety and tolerability of prucalopride in severe chronic constipation--a 12-week, randomized, doubleblind, placebo-controlled study. Aliment Pharmacol Ther 2009;29:315328.

55. Sloots CE, Poen AC, Kerstens R, et al. Effects of prucalopride on colonic transit, anorectal function and bowel habits in patients with chronic constipation. Aliment Pharmacol Ther 2002;16:759-767.

56. Sloots CE, Rykx A, Cools M, Kerstens R, De Pauw M. Efficacy and safety of prucalopride in patients with chronic noncancer pain suffering from opioid-induced constipation. Dig Dis Sci 2010;55:2912-2921.

57. Tack J, van Outryve M, Beyens G, Kerstens R, Vandeplassche L. Prucalopride (Resolor) in the treatment of severe chronic constipation in patients dissatisfied with laxatives. Gut 2009;58:357-365.

58. Yiannakou Y, Piessevaux H, Bouchoucha M, et al. A randomized, double-blind, placebo-controlled, phase 3 trial to evaluate the efficacy, safety, and tolerability of prucalopride in men with chronic constipation. Am J Gastroenterol 2015;110:741-718.

59. Emmanuel A, Cools M, Vandeplassche L, Kerstens R. Prucalopride improves bowel function and colonic transit time in patients with chronic constipation: an integrated analysis. Am J Gastroenterol 2014;109:887894.

60. Coremans G. Prucalopride: the evidence for its use in the treatment of chronic constipation. Core Evid 2008;3:45-54.

61. Pennant M, Orlando R, Barton P, Bayliss S, Routh K, Meads C. Prucalopride for the treatment of women with chronic constipation in whom standard laxative regimens have failed to provide adequate relief. Health Technol Assess 2011;15(suppl 1):43-50.

62. Shin A, Camilleri M, Kolar G, Erwin P, West CP, Murad MH. Systematic review with meta-analysis: highly selective $5-\mathrm{HT}_{4}$ agonists (prucalopride, velusetrag or naronapride) in chronic constipation. Aliment Pharmacol Ther 2014;39:239-253.

63. Tack J, Camilleri M, Chang L, et al. Systematic review: cardiovascular safety profile of $5-\mathrm{HT}_{4}$ agonists developed for gastrointestinal disorders. Aliment Pharmacol Ther 2012;35:745-767.

64. Choi SC, Zou D, Ke MY, et al. Chronic constipation-associated symptoms in Asians and non-Asians, and effects of 12-week prucalopride treatment: a pooled analysis of 4 randomized, placebo-controlled trials. J Dig Dis Published Online First: 15 Dec 2014. doi: 10.1111/17512980.12219

65. Ke M, Tack J, Quigley EM, et al. Effect of prucalopride in the treatment of chronic constipation in Asian and non-Asian women: a pooled analysis of 4 randomized, placebo-controlled studies. J Neurogastroenterol Motil 2014;20:458-468.

66. Corsetti M, Tack J. New pharmacological treatment options for chronic constipation. Expert Opin Pharmacother 2014;15:927-941.

67. Keating GM. Prucalopride: a review of its use in the management of chronic constipation. Drugs 2013;73:1935-1950.

68. Diederen K, Mugie SM, Benninga MA. Efficacy and safety of prucalopride in adults and children with chronic constipation. Expert Opin Pharmacother 2015;16:407-416.

69. Tack J, Corsetti M. Prucalopride: evaluation of the pharmacokinetics, pharmacodynamics, efficacy and safety in the treatment of chronic constipation. Expert Opin Drug Metab Toxicol 2012;8:1327-1335. 